UDK $577.1: 61$

ISSN 1452-8258

J Med Biochem 37: 470-475, 2018

Original paper

Originalni naučni rad

\title{
ARE VASPIN AND OMENTIN-1 RELATED TO INSULIN RESISTANCE, BLOOD PRESSURE AND INFLAMMATION IN NAFLD PATIENTS?
}

\author{
DA LI SU VASPIN I OMETIN-1 POVEZANI SA INSULINSKOM REZISTENCIJOM, \\ KRVNIM PRITISKOM I INFLAMACIJOM KOD NAFLD PACIJENATA? \\ Fereshteh Aliasghari 1,2, Azimeh Izadi 1,2, Masoumeh Jabbari², Bahareh Imani3, \\ Bahram Pourghassem Gargari ${ }^{1}$, Foad Asjodi ${ }^{4}$, Sara Ebrahimi ${ }^{5}$ \\ ${ }^{1}$ Department of Biochemistry and Diet Therapy, Nutrition Research Center, \\ Faculty of Nutrition and Food Science, Tabriz University of Medical Sciences, Tabriz, Iran \\ ${ }^{2}$ Student Research Committee, Tabriz University of Medical Sciences, Tabriz, Iran \\ ${ }^{3}$ Mashhad University of Medical Sciences, Mashhad, Iran \\ ${ }^{4}$ Sport Nutrition board in the IFMARC (Iran Football Medical Assessment and Research Center), Tehran, Iran \\ ${ }^{5}$ School of Exercise and Nutrition Science, Faculty of Health Science, Deakin University, Australia
}

\section{Summary}

Background: Non-alcoholic fatty liver disease (NAFLD), the hepatic manifestation of insulin resistance, is the most common cause of chronic liver. The present study aimed to investigate the roles of vaspin and omentin-1 in the NAFLD-related pathology including IR, inflammation and elevated blood pressure.

Methods: This cross-sectional study was conducted among 83 NAFLD patients in Jahrom, Iran. Plasma levels of omentin-1, vaspin, hs-CRP and IL-6 were measured. Anthropometric indices, lipid profiles, liver enzymes as well as abdominal ultrasonography were assessed.

Results: Partial correlations controlling for age and sex showed significant positive correlation between vaspin and fasting blood sugar (FBS), insulin, HOMA-IR, and hs-CRP. It has been observed that omentin negatively correlated with glucose levels. Moreover, a marginally significant association has been found between omentin levels and systolic blood pressure (SBP).

Conclusions: This study shows that vaspin and omentin-1 are associated with inflammation, insulin resistance and serum glucose levels in patients with NAFLD.

Keywords: insulin resistance, NAFLS, adipokines, lipid profiles, inflammation

\section{Kratak sadržaj}

Uvod: Oboljenje ne-alkoholna masna jetra (NAFLD) je posledica promene na jetri usled insulinske rezistencije je najčešći uzrok hroničnog oboljenja jetre. Ovaj rad ima za cilj ispitivanje uloge vaspina i ometina-1 u NAFLDpatologiji, inflamaciji i povećanom krvnom pritisku.

Metode: Ispitivanja su izvedena na 83 NAFLD pacijenta $u$ Jahrom-u, Iran. Mereni su nivoi ometina-1, vaspina, hsCRP i IL-6. Ispitivani su antropometrijski parametri, profil lipida, jetreni enzimi i abdominalna ultrasonografija.

Rezultati: Delimičnom korelacijom između pola i starosti ukazala su na pozitivnu korelaciju između vaspina i nivoa glukoze u krvi (FBS), insulina, HOMA-IR i hs-CRP. Nađeno je da je ometin u negativnoj korelaciji sa nivoima glukoze. Međutim, marginalno značajna veza je nađena između nivoa ometina i sistolnog krvnog pritiska (SBP).

Zaključak: Rezultati su pokazali da vaspin i ometion-1 su praćeni inflamacijom, insulinskom rezistencijom u nivoima glukoze u serumu kod pacijenata sa NAFLD.

Ključne reči: insulinska rezistencija, NAFLD, adipokini, lipidni profil, inflamacija

Address for correspondence:

Sara Ebrahimi

School of Exercise and Nutrition Science,

Faculty of Health Science, Deakin University, Australia

Tel: 0098-917-1922566

e-mail: saraebrahimi123@gmail.com 


\section{Introduction}

The incidence of non-alcoholic fatty liver disease (NAFLD) is increasing due to the growing epidemics of obesity (1). NAFLD is considered as one of the leading causes of chronic liver disease and encompasses a wide spectrum of liver diseases, ranging from a simple fatty liver (steatosis) to steatohepatitis, fibrosis, or cirrhosis (1). Given the widespread increasing rates of NAFLD, a better understanding of its pathophysiology is of significant importance. NAFLD is considered to be the hepatic component of metabolic syndrome (MS) and is associated with visceral obesity, with insulin resistance (IR) playing a key role (2), however, the pathogenesis remains unclear.

On the basis of the National Cholesterol Education Program Adult Treatment Panel III, in the presence of three out of five criteria which include a high waist circumference, high TG or reduced highdensity lipoprotein (HDL)-cholesterol levels, elevated blood pressure, and high fasting glucose levels or a diagnosis of T2DM, MS can be diagnosed (3). Approximately $90 \%$ of the NAFLD patients present more than one component of the MS, and about $33 \%$ of the patients meet the criteria for the MS (4). Additionally, in both cross-sectional and prospective studies, NAFLD has been associated with an increased prevalence of hypertension (5).

The ability of insulin to inhibit glucose production is impaired in patients with metabolic syndrome or NAFLD, which results in mild hyperglycemia, which in turn stimulates insulin secretion and leads to hyperinsulinemia. Thus fasting hyperglycemia and hyperinsulinemia are consequences of hepatic insulin resistance and correlate positively with liver fat, even independent of BMI (6).

In addition, pro-inflammatory cytokines play important roles in fatty liver diseases (7). In this regard, several studies suggested an important role for IL-6 in NAFLD $(8,9)$.

Derived from adipose tissue, multiple regulating proteins, so-called adipokines, are secreted molecules with diverse local, peripheral and central functions.

A growing body of evidence reported that an impaired pattern in adipokine secretion could play a pivotal role in the development of metabolic syndrome, including NAFLD and the progression to $\mathrm{NASH}(1)$.

Omentin-1 is a circulating adipokine and has been identi ed as an adipokine that may improve insulin sensitivity. Decreased omentin expression was shown to be implicated in a variety of chronic in ammatory diseases (10).

Visceral adipose tissue-derived serine protease inhibitor (vaspin) is a member of the serine protease inhibitor family (serpin) and is a recently discovered adipokine (11). Serum vaspin concentration is report- ed to be increased in patients with NAFLD and has been found to be positively associated with liver fibrosis scores and C-reactive protein (12). Regarding its recent discovery, there are inconsistent reports of the role of vaspin in hepatic fibrosis.

In this study, we provide insights into the roles of vaspin and omentin-1 in the NAFLD-related pathology including IR, inflammation and elevated blood pressure.

\section{Materials and Methods}

\section{Study Setting and Design and Subjects}

This cross-sectional study surveyed the association of inflammatory markers including omentin 1 and vaspin as well as Insulin resistance and blood pressure in NAFLD patients. An overall of 83 patients from Jahrom University of medical science in Iran participated in this study. Age group between 20 and 50 years with the history of NAFLD regarded as Inclusion criteria. Exclusion criteria included chronic diseases including kidney diseases, diabetes and malignancy, smoking, menopause and pregnancy and lactation. The aim of the study was explained and the written consent was obtained from all patients. Furthermore, the ethical committee of Jahrom University of Medical Sciences approved this study.

\section{Anthropometric measurements}

Weight and height were measured by seca scale (Hamburg Germany) and a stadiometer attached to the scale respectively. Body mass index (BMI) was calculated from measurement height in meters and weight in kilograms. Waist circumference measurements made at the approximate midpoint between the lower margin of the last palpable rib and the top of the iliac crest. Hip circumference measurements have been taken around the widest portion of the buttocks and waist-to-hip ratio (WHR) was determined.

\section{Sample collection and laboratory assessment}

Approximately $10 \mathrm{~mL}$ of venous blood samples were taken from all patients after a 12-h overnight fasting to evaluate serum concentration of adipokines and lipid profiles, liver enzymes. All the samples centrifuged at $4{ }^{\circ} \mathrm{C}$ for $10 \mathrm{~min}$ at 2500 r.p.m to separate serum and plasma and were frozen at $-80^{\circ} \mathrm{C}$.

Alanine aminotransferase (ALT) and aspartate aminotransferase (AST) as well as serum vaspin and omentin-1, hs-CRP, IL-6 were analyzed by Commercial ELISA kit. Total cholesterol, HDL cholesterol (high-density lipoprotein-cholesterol) and triglyceride levels were analyzed by enzymatic procedures. If triglyceride concentration was $<4.5 \mathrm{mmol} / \mathrm{L}$, LDL cholesterol levels 
was calculated by the Friedewald equation. HDL and TG levels reported in molar concentration.

All the abdominal ultrasonography was taken through an East Medical sonographic scanner equipped with a convex $3.5 \mathrm{MHz}$ browser by a radiology specialist.

After a $12 \mathrm{~h}$ fasting, FBS and Insulin level was evaluated by the hexokinase/glucose-6-phosphate dehydrogenase method; HbA1c Insulin resistance (homeostasis model assessment insulin resistance, HOMA-IR) were calculated according to Mathews et al. (13). HOMA-IR values higher than 2.70 showed insulin resistance, as identified in the Brazilian Metabolic Syndrome Study (14). The blood pressure was measured in standard conditions.

\section{Statistical analysis}

Statistical analysis was performed using Statistical Package for Social Sciences (SPSS, Chicago, USA) software, version 21.0 for Windows. Data are presented as frequencies for nominal variables and as means \pm standard deviation (SD) for ordinal variables.

Associations between adipokines and inflammatory biomarkers, SBP AND DBP, and parameters of glycemic status were analyzed using Partial correlation controlling for age and sex. A P value of $<0.05$ was considered statistically significant.

Table I Demographic and anthropometric characteristics in NAFLD patients.

\begin{tabular}{|l|c|}
\hline Characteristics & Patients $(\mathrm{n}=83)$ \\
\hline Gender $(\mathrm{n}, \%)$ & $42(50.6 \%)$ \\
Male & $41(49.4 \%)$ \\
Female & $49(59.0 \%)$ \\
\hline Grade of fatty liver $(\mathrm{n}, \%)$ & $25(30.1 \%)$ \\
Grade I & $9(10.8 \%)$ \\
Grade I & $35(42.2 \%)$ \\
Grade III & $35(42.2 \%)$ \\
\hline Physical activity & $13(15.7 \%)$ \\
Light (\%) & $36.71 \pm 7.21$ \\
Moderate $(\%)$ & $83.07 \pm 12.83$ \\
Severe (\%) & $29.41 \pm 4.18$ \\
\hline Age (years) & $99.07 \pm 10.43$ \\
\hline Weight $(\mathrm{kg})$ & $104.85 \pm 7.03$ \\
\hline BMI $\left(\mathrm{kg} / \mathrm{m}^{2}\right)$ & $0.94 \pm 0.08$ \\
\hline WC $(\mathrm{cm})$ & $32.70 \pm 7.70$ \\
\hline HC $(\mathrm{cm})$ & \\
\hline WHR & \\
\hline Fat percentage & \\
\hline
\end{tabular}

Mean \pm standard deviation is reported for age, weight, $\mathrm{BMI}$, WC and WHR. BMI: body mass index, WC: waist circumference, WHR: waist to hip ratio.

\section{Results}

Demographic and anthropometric characteristics of patients are shown in Table I. The biochemical parameters of patients including lipid profile, liver enzymes, inflammatory biomarkers and adipokines are shown in Table II and III, respectively. Partial correlations controlling for age and sex showed that vaspin is significantly associated with FBS, insulin, HOMA-IR, and inversely associated with QUICKI (Table IV). As it is observed, omentin levels correlated negatively with glucose levels. Similarly, partial correlations controlling for age and sex showed that vaspin is significantly associated with hs-CRP. Additionally, omentin levels showed a marginally significant association with SBP (Table IV).

Table II The values of biochemical parameters of patients are presented in Table II.

\begin{tabular}{|l|c|}
\hline Variables & Patients $(\mathrm{n}=83)$ \\
\hline Triglyceride (mmol/L) & $10.85 \pm 3.08$ \\
\hline Total cholesterol (mmol/L) & $11.64 \pm 2.01$ \\
\hline High-density lipoprotein (HDL) (mmol/L) & $2.15 \pm 0.48$ \\
\hline Low-density lipoprotein (LDL) (mmol/L) & $8.29 \pm 1.55$ \\
\hline Aspartate aminotransferase (AST) (U/L) & $41.99 \pm 8.84$ \\
\hline Alanine transaminase (ALT) (U/L) & $40.85 \pm 8.76$ \\
\hline
\end{tabular}

Mean \pm standard deviation is reported.

Table III The values of glycemic parameters, blood pressure and inflammatory biomarkers of patients.

\begin{tabular}{|l|c|}
\hline Variables & Patients $(\mathrm{n}=83)$ \\
\hline FBS $(\mathrm{mmol} / \mathrm{L})$ & $5.3 \pm 0.4$ \\
\hline Insulin $(\mu \mathrm{IU} / \mathrm{mL})$ & $15.44 \pm 2.89$ \\
\hline HOMA-IR & $3.64 \pm 0.73$ \\
\hline HOMA-B & $178.13 \pm 47.37$ \\
\hline QUICKI & $0.317 \pm 0.009$ \\
\hline SBP $(\mathrm{mmHg})$ & $12.57 \pm 0.91$ \\
\hline DBP $(\mathrm{mmHg})$ & $7.70 \pm 0.87$ \\
\hline IL6 $(\mathrm{pg} / \mathrm{mL})$ & $72.11 \pm 76.29$ \\
\hline hs-CRP $(\mathrm{mg} / \mathrm{L})$ & $2.75 \pm 1.27$ \\
\hline Omentin $(\mathrm{ng} / \mathrm{mL})$ & $263.45 \pm 110.70$ \\
\hline Vaspin $(\mathrm{ng} / \mathrm{mL})$ & $6.83 \pm 2.37$ \\
\hline
\end{tabular}

Mean \pm SD is reported. 
Table IV Evaluation of correlations between serum adipokines, and insulin resistance in the subjects.

\begin{tabular}{|c|c|c|c|c|}
\hline & \multicolumn{2}{|c|}{ Vaspin } & \multicolumn{2}{|c|}{ Omentin-1 (ng/mL) } \\
\hline & $r$ & $\mathrm{p}$ & r & $\mathrm{p}$ \\
\hline FBS & 0.216 & 0.53 & -0.213 & 0.05 \\
\hline Insulin & 0.290 & 0.009 & \multicolumn{2}{|l|}{ NS } \\
\hline HOMA-IR & 0.324 & 0.003 & \multicolumn{2}{|l|}{ NS } \\
\hline HOMA-B & \multicolumn{2}{|l|}{ NS } & \multicolumn{2}{|l|}{ NS } \\
\hline QUICKI & -0.330 & 0.003 & \multicolumn{2}{|l|}{ NS } \\
\hline SBP & \multicolumn{2}{|l|}{ NS } & -0.210 & 0.06 \\
\hline DBP & \multicolumn{2}{|l|}{ NS } & \multicolumn{2}{|l|}{ NS } \\
\hline IL6 & 0.395 & $<0.001$ & NS & \\
\hline $\mathrm{Hs}-\mathrm{CRP}$ & 0.296 & 0.007 & NS & \\
\hline
\end{tabular}

Spearman's correlation coefficients were used, $\mathrm{P}<0.05$ is statistically significant; NS: non-significant.

\section{Discussion}

NAFLD is a spectrum of metabolic abnormalities disturbance including obesity, insulin resistance, hypertension, and impaired plasma glucose and lipid profile, so it can be regarded as a hepatic manifestation of metabolic syndrome $(15,16)$. One of the most prominent features of this syndrome is obesity-related insulin resistance and inflammation that identified by raised inflammatory cytokines level and pro-inflammatory pathway activation (17). Numerous studies have suggested adipokines as a Link between metabolic disturbances such as insulin resistance and inflammation that involved in the pathogenesis or progression of NAFLD $(1,18,19)$. In this study, we detected a significant correlation between vaspin and insulin resistance, hs-CRP and IL- 6 in patients with NAFLD. Omentin showed a marginally significant correlation with glucose homeostasis, but no association was found for inflammatory cytokines. In addition, a significant association between omentin and SBP observed in patients with NAFLD.

Adipokines, in adipose tissues, based on their effects on inflammatory responses are classified into two groups: pro- and anti-inflammatory adipokines (20). Recent studies indicated anti-inflammatory effects of vaspin and omentin in obesity and insulin resistance conditions (20-22). Vaspin, a member of the serine protease inhibitor family, is an insulin-sensitizing adipokine which upregulated in metabolic diseases to compensate insulin resistance and inflammatory complication and furthermore may play an inhibition role in brosis development and progression $(23,24)$. This observation suggested the possible contribution of vaspin in liver brogenesis (25). In our study, vaspin correlated positively with insulin resist- ance which provides support to the mentioned compensatory mechanism of vaspin overexpression in human adipose tissue in IR condition (23, 25-27). Although the exact mechanisms by which vaspin improved insulin sensitivity is unclear, studies suggested that vaspin may antagonize the effect of proteases that are up-regulated in IR states $(23,26)$. Vaspin also decreased the expression of leptin, TNF- $\alpha$, and resistin, so ameliorate in ammatory process that may effectively improve IR (10). In the present study, Keeping with previous research, vaspin associated significantly with hs-CRP and IL-6 in study participants $(12,28-31)$. Inflammatory process amelioration may aid in impaired insulin sensitivity $(25,29)$. In contrast, a series of previous studies revealed a negative association between hs-CRP and vaspin levels $(32,33)$. These controversies in reported results may in part be due to the different influences of various chronic inflammatory diseases on vaspin concentrations. Thus, further studies with larger participants are needed to investigated vaspin and inflammatory cytokines associations $(34,35)$.

Clinical studies demonstrated the close relationship between plasma vaspin levels and atherosclerosis, so, vaspin might be involved in the coronary artery disease (CAD) process (35-37). Experiments also indicated that vaspin could inhibit the release of key inflammatory markers in vascular smooth muscle cells and prevent FFA-induced apoptosis in endothelial cells, also vaspin could inhibit proliferation of vascular smooth muscle cells which induced by chemokinesis inactivation of ROS and MAPK, $\mathrm{PI} 3 \mathrm{~K} / \mathrm{Akt}$, and NF-kB signaling $(12,36)$. In Kameshima et all study, it was indicated that vaspin prevents elevation of blood pressure through peripheral arterial hypertrophy inhibition that may induce via antioxidative and anti-inflammatory mechanisms (38). In addition, vaspin augments acetylcholine-induced endothelium-dependent relaxation through the inhibition of acetylcholinesterase activity (AChE) activity (39).

However, in the present study, we did not find any significant association between vaspin level and blood pressure. This could be explained by the fact that the blood pressure of the participants was in normal range, thus there is no association between adipokines and blood pressure.

Plasma omentin levels are significantly lower in obese subjects, diabetic patients, and in people with chronic inflammatory diseases compared to healthy ones $(20,26,27,30,31,35,40)$. A negative correlation has been reported between plasma omentin levels and anthropometric indices including $\mathrm{BMI}$ and waist circumference and, fasting insulin, and HOMA. Similarly, we have found an inverse association between omentin concentration and FBS. The association between omentin and these metabolic indices suggests that omentin may be a protective factor 
against the obesity-related complications (41). Although these findings suggest that omentin levels may reduced in NAFLD, there is evidence of increased levels of omentin in patients with NAFLD (42). More studies are needed to understand the exact roles of omentin in obesity and its related disorder. More studies are needed to identify reasons for these paradoxical findings.

Omentin could reduce the activation of nuclear factor kappa-light-chain- enhancer of activated B cell (NF-KB), and decreases the inflammatory cytokines such as CRP, IL- 6, and TNF- $\alpha$ (34). In the present study, we did not find any significant association between omentin levels and inflammatory cytokines, even though a negative correlation observed between serum omentin and systolic blood pressure. Previous animal studies indicated that omentin improves endothelial functions and prevented blood pressure elevation in rats through endothelium-dependent relaxation. It has been determined that omentin increases the phosphorylation of eNOS and consequently induced relaxation in endothelium $(35,39)$. As mentioned, obese subjects have significantly reduced omentin levels, so omentin low level may play at least in part a key role in accompanied hyper-

\section{References}

1. Bekaert M, Verhelst X, Geerts A, Lapauw B, Calders P. Association of recently described adipokines with liver histology in biopsy proven non alcoholic fatty liver disease: a systematic review. Obesity Reviews 2016; 17(1): 68-80.

2. Abenavoli L, Milic N, Di Renzo L, Preveden T, Medi Stojanoska M, De Lorenzo A. Metabolic aspects of adult patients with nonalcoholic fatty liver disease. World Journal of Gastroenterology 2016; 22(31): 7006.

3. Panel NCEPNE. Third report of the National Cholesterol Education Program (NCEP) expert panel on detection, evaluation, and treatment of high blood cholesterol in adults (Adult Treatment Panel III) final report. Circulation 2002; 106(25): 3143.

4. Masarone M, Federico A, Abenavoli L, Loguercio C, Persico M. Non alcoholic fatty liver: epidemiology and natural history. Reviews on recent clinical trials 2014; 9(3): 126-33.

5. Sung K-C, Wild SH, Byrne CD. Development of new fatty liver, or resolution of existing fatty liver, over five years of follow-up, and risk of incident hypertension. Journal of Hepatology 2014; 60(5): 1040-5.

6. Yki-Järvinen $\mathrm{H}$. Non-alcoholic fatty liver disease as a cause and a consequence of metabolic syndrome. The Lancet Diabetes \& Endocrinology 2014; 2(11): 901-10.

7. Tilg $H$, Diehl AM. Cytokines in alcoholic and nonalcoholic steatohepatitis. The New England Journal of Medicine 2000; 343: 1467-76. tension in obese patients (40). Although we did not observe a significant correlation between omentin levels and inflammatory cytokines, previous studies indicated positive associations. Taken together, further studies are needed to investigate whether omentin level elevation in NAFLD patients is a compensatory mechanism to insulin resistance and inflammatory states of disease (42).

In conclusion, the present study indicated raised serum levels of omentin and vaspin in patients with NAFLD. Both these adipokines seem to play a major role in the development and progression of NAFLD. Omentin and vaspin may have a potential role in glucose metabolism, inflammation process, and blood pressure as well. Altogether, the present study adds to a growing literature supporting that novel adipokines may contribute to the clinical expression of NAFLD. Future studies may continue to explore a new area to assess the possible role of these novel adipokines in the pathogens of NAFLD.

\section{Conflict of interest statement}

The authors stated that they have no conflicts of interest regarding the publication of this article.

8. Abiru S, Migita K, Maeda Y, Daikoku M, Ito M, Ohata K, et al. Serum cytokine and soluble cytokine receptor levels in patients with non alcoholic steatohepatitis. Liver International 2006; 26(1): 39-45.

9. Haukeland JW, Damås JK, Konopski Z, Løberg EM, Haaland T, Goverud I, et al. Systemic inflammation in nonalcoholic fatty liver disease is characterized by elevated levels of CCL2. Journal of Hepatology 2006; 44(6): 1167-74.

10. Yang R-Z, Lee M-J, Hu H, Pray J, Wu H-B, Hansen BC, et al. Identification of omentin as a novel depot-specific adipokine in human adipose tissue: possible role in modulating insulin action. American Journal of Physiology-Endocrinology and Metabolism 2006; 290(6): E1253-E61.

11. Heiker JT. Vaspin (serpinA12) in obesity, insulin resistance, and inflammation. Journal of Peptide Science 2014; 20(5): 299-306.

12. Aktas B, Yilmaz Y, Eren F, Yonal O, Kurt R, Alahdab YO, et al. Serum levels of vaspin, obestatin, and apelin-36 in patients with nonalcoholic fatty liver disease. Metabolism 2011; 60(4): 544-9.

13. Matthews D, Hosker J, Rudenski A, Naylor B, Treacher D, Turner R. Homeostasis model assessment: insulin resistance and $\beta$-cell function from fasting plasma glucose and insulin concentrations in man. Diabetologia 1985; 28(7): 412-9.

14. Geloneze B, Vasques ACJ, Stabe CFC, Pareja JC, Rosado LEFPd, Queiroz ECd, et al. HOMA1-IR and HOMA2-IR indexes in identifying insulin resistance and metabolic 
syndrome: Brazilian Metabolic Syndrome Study (BRAMS). Arquivos Brasileiros de Endocrinologia \& Metabologia 2009; 53(2): 281-7.

15. Dietrich P, Hellerbrand C. Non-alcoholic fatty liver disease, obesity and the metabolic syndrome. Best Practice \& Research Clinical Gastroenterology 2014; 28(4): 637-53.

16. Asrih M, Jornayvaz FR. Metabolic syndrome and nonalcoholic fatty liver disease: Is insulin resistance the link? Molecular and cellular endocrinology 2015; 418: 55-65.

17. Asrih $M$, Jornayvaz FR. Inflammation as a potential link between nonalcoholic fatty liver disease and insulin resistance. Journal of Endocrinology 2013; 218(3): R25-R36.

18. Al Rifai M, Silverman MG, Nasir K, Budoff MJ, Blankstein $R$, Szklo $M$, et al. The association of nonalcoholic fatty liver disease, obesity, and metabolic syndrome, with systemic inflammation and subclinical atherosclerosis: the Multi-Ethnic Study of Atherosclerosis (MESA). Atherosclerosis 2015; 239(2): 629-33.

19. Ramadan RA. Serum vaspin and insulin resistance: predictors of steatosis and fibrosis in Egyptian patients with genotype 4 chronic hepatitis C. Advance Laboratory Medicine International 2013; 3(3): 48-64.

20. Collinson P. Laboratory medicine is faced with the evolution of medical practice. J Med Biochem 2017; 36: 211-15.

21. Zhou J-Y, Chan L, Zhou S-W. Omentin: linking metabolic syndrome and cardiovascular disease. Current Vascular Pharmacology 2014; 12(1): 136-43.

22. Coimbra S, Catarino C, Santos Silva A. The triad psoriasis-obesity-adipokine profile. Journal of the European Academy of Dermatology and Venereology 2016; 30(11): 1876-85.

23. Esteghamati A, Noshad S, Mousavizadeh M, Zandieh A, Nakhjavani M. Association of vaspin with metabolic syndrome: the pivotal role of insulin resistance. Diabetes \& Metabolism Journal 2014; 38(2): 143-9.

24. Alkady MM, Abdel-Messeih PL, Nosseir NM. Assessment of serum levels of the adipocytokine chemerin in colorectal cancer patients. J Med Biochem 2018; 37: 313-9.

25. Kukla M, Zwirska Korczala K, Gabriel A, Waluga M, Warakomska I, Szczygiel B, et al. Chemerin, vaspin and insulin resistance in chronic hepatitis $C$. Journal of Viral Hepatitis 2010; 17(9): 661-7.

26. Senolt L, Polanska M, Filkova M, Cerezo LA, Pavelka K, Gay $S$, et al. Vaspin and omentin: new adipokines differentially regulated at the site of inflammation in rheumatoid arthritis. Annals of the Rheumatic Diseases 2010; 69: 1410-11.

27. Schäffler $A$, Neumeier $M$, Herfarth $H$, Fürst $A$, Schölmerich J, Büchler C. Genomic structure of human omentin, a new adipocytokine expressed in omental adipose tissue. Biochimica et Biophysica Acta (BBA)-Gene Structure and Expression 2005; 1732(1): 96-102.

28. Engin-Ustun $Y$, Tonguç E, Var T, Deveer R, Yilmaz N, Danisman N, et al. Vaspin and C-reactive protein levels in hyperemesis gravidarum. Eur Rev Med Pharmacol Sci 2013; 17(1): 138-40.
29. Napitupulu RE, Meiliana A, Wijaya A. Correlation of Progranulin, Granulin, Adiponectin and Vaspin with Metaflammation (hs-CRP) in Indonesian Obese Men. The Indonesian Biomedical Journal 2013; 5(2): 107-14.

30. Auguet T, Quintero $Y$, Riesco D, Morancho B, Terra X, Crescenti $A$, et al. New adipokines vaspin and omentin. Circulating levels and gene expression in adipose tissue from morbidly obese women. BMC Medical Genetics 2011; 12(1): 60 .

31. Hong H-R, Ha C-D, Jin Y-Y, Kang H-S. The effect of physical activity on serum IL-6 and vaspin levels in late elementary school children. Journal of Exercise Nutrition Biochemistry 2015; 19(2): 99.

32. Wang $H$, Wang $Q$. Low vaspin levels are related to endothelial dysfunction in patients with ankylosing spondylitis. Brazilian Journal of Medical and Biological Research 2016; 49(7).

33. Esaki E, Adachi $H$, Hirai $Y$, Yamagishi S-i, Kakuma T, Enomoto $M$, et al. Serum vaspin levels are positively associated with carotid atherosclerosis in a general population. Atherosclerosis 2014; 233(1): 248-52.

34. Tan BK, Adya R, Farhatullah S, Lewandowski KC, O'Hare $P$, Lehnert $H$, et al. Omentin-1, a novel adipokine, is decreased in overweight insulin-resistant women with polycystic ovary syndrome. Diabetes 2008; 57(4): 801-8.

35. Grygiel-Górniak B, Grzelak T, Czyżewska K, Puszczewicz $M$. Chemerin, resistin, and adiponectin in patients with connective tissue diseases. J Med Biochem 2018; 37: $148-54$

36. Zhang B, Peng W, Wang K, Li H, Xu Y. Vaspin as a Prognostic Marker in Patients with Acute Myocardial Infarction. Heart, Lung and Circulation 2016; 25(3): 257-64.

37. Karbek B, Bozkurt N, Topaloglu O, Aslan M, Gungunes A, Cakal E, et al. Relationship of vaspin and apelin levels with insulin resistance and atherosclerosis in metabolic syndrome. Minerva Endocrinol 2014; 39(2): 99-105.

38. Kameshima S, Sakamoto Y, Okada M, Yamawaki $H$. Vaspin prevents elevation of blood pressure through inhibition of peripheral vascular remodelling in spontaneously hypertensive rats. Acta Physiologica 2015.

39. Kameshima S, Yamada K, Morita T, Okada M, Yamawaki $\mathrm{H}$. Visceral adipose tissue derived serine protease inhibitor augments acetylcholine induced relaxation via the inhibition of acetylcholine esterase activity in rat isolated mesenteric artery. Acta Physiologica 2016; 216(2): 203-10.

40. Tan BK, Adya R, Randeva HS. Omentin: a novel link between inflammation, diabesity, and cardiovascular disease. Trends in cardiovascular medicine 2010; 20(5): 143-8.

41. de Souza Batista CM, Yang R-Z, Lee M-J, Glynn NM, Yu D-Z, Pray J, et al. Omentin plasma levels and gene expression are decreased in obesity. Diabetes 2007; 56(6): 1655-61.

42. Yilmaz Y, Yonal O, Kurt R, Alahdab YO, Eren F, Ozdogan $O$, et al. Serum levels of omentin, chemerin and adipsin in patients with biopsy-proven nonalcoholic fatty liver disease. Scandinavian Journal of Gastroenterology 2011; 46(1): 91-7. 